Western University

Scholarship@Western

Aboriginal Policy Research Consortium International (APRCi)

2007

\title{
Rethinking Devolution: Challenges for Aboriginal Resource Management in the Yukon Territory
}

David C. Natcher

Susan Davis

Follow this and additional works at: https://ir.lib.uwo.ca/aprci

Part of the Environmental Policy Commons

Citation of this paper:

Natcher, David C. and Davis, Susan, "Rethinking Devolution: Challenges for Aboriginal Resource Management in the Yukon Territory" (2007). Aboriginal Policy Research Consortium International (APRCi). 204.

https://ir.lib.uwo.ca/aprci/204 
This article was downloaded by: [University of Western Ontario]

On: 30 October 2012, At: 13:15

Publisher: Routledge

Informa Ltd Registered in England and Wales Registered Number: 1072954 Registered office: Mortimer House, 37-41 Mortimer Street, London W1T 3J H, UK

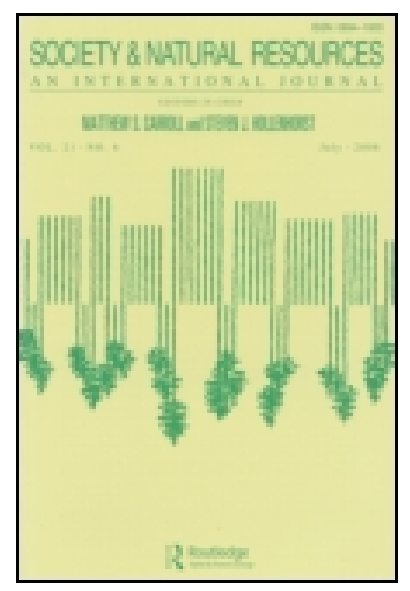

\title{
Society \& Natural Resources: An International J ournal
}

Publication details, including instructions for authors and subscription information:

http:// www. tandfonline.com/loi/ usnr20

\section{Rethinking Devolution: Challenges for Aboriginal Resource Management in the Yukon Territory}

\author{
David C. Natcher ${ }^{a} \&$ Susan Davis ${ }^{b}$ \\ a Department of Anthropology, Canada Research Chair in Aboriginal \\ Studies, Memorial University of Newfoundland, St. J ohn's, \\ Newfoundland, Canada \\ ${ }^{b}$ Lands and Resource Department, Little Salmon Carmacks First \\ Nation, Carmacks, Yukon Territory, Canada \\ Version of record first published: 01 Mar 2007.
}

To cite this article: David C. Natcher \& Susan Davis (2007): Rethinking Devolution: Challenges for Aboriginal Resource Management in the Yukon Territory, Society \& Natural Resources: An International J ournal, 20:3, 271-279

To link to this article: http:// dx.doi.org/ 10.1080/08941920601117405

\section{PLEASE SCROLL DOWN FOR ARTICLE}

Full terms and conditions of use: http://www.tandfonline.com/page/terms-and-conditions

This article may be used for research, teaching, and private study purposes. Any substantial or systematic reproduction, redistribution, reselling, loan, sub-licensing, systematic supply, or distribution in any form to anyone is expressly forbidden.

The publisher does not give any warranty express or implied or make any representation that the contents will be complete or accurate or up to date. The accuracy of any instructions, formulae, and drug doses should be independently verified with primary sources. The publisher shall not be liable for any loss, actions, claims, proceedings, demand, or costs or damages whatsoever or howsoever caused arising directly or indirectly in connection with or arising out of the use of this material. 


\title{
Policy Review
}

\section{Rethinking Devolution: Challenges for Aboriginal Resource Management in the Yukon Territory}

\author{
DAVID C. NATCHER
}

\author{
Department of Anthropology, Canada Research Chair in Aboriginal \\ Studies, Memorial University of Newfoundland, St. John's, \\ Newfoundland, Canada
}

\section{SUSAN DAVIS}

Lands and Resource Department, Little Salmon Carmacks First Nation, Carmacks, Yukon Territory, Canada

\begin{abstract}
After decades of state administration, indigenous peoples throughout the world are now succeeding, to varying degrees, in the reimplementation of self-governing institutions and administrative processes. This reorientation has been most observable in the context of natural resource management, where a major policy trend has been to devolve state authority and administrative responsibility directly to local levels. While the language of devolution and local control now permeates local-state interaction, in many cases the new institutions that have been created following devolution have little resemblance to indigenous forms of management. In this article, we present some of the institutional and ideological factors that continue to influence the way in which lands and resources are managed by First Nations in the Yukon Territory of Canada. In doing so, we identify the difficulties of applying indigenous cultural ideals into a management process that continues to be derived from nonindigenous values and principles.
\end{abstract}

Keywords aboriginal, devolution, land claims, resource management, Yukon Territory

After decades of state administration, indigenous peoples throughout the world are now succeeding, to varying degrees, in the reimplementation of self-governing institutions and administrative processes. This reorientation has been most observable in the context of natural resource management, where a major policy trend has been to devolve state authority and administrative responsibility directly to local levels (Ribot and Larson 2005). Long criticized for being unresponsive to local needs and impervious to local participation, state systems of resource management are now being supplanted by local forms of governance. Advocated on grounds of efficiency and sociopolitical equity, devolution has in some cases succeeded in alleviating conditions

Received 16 August 2005; accepted 19 April 2006.

Address correspondence to David C. Natcher, Assistant Professor, Department of Anthropology, Canada Research Chair in Aboriginal Studies, Memorial University of Newfoundland, St. John's, NL A1C 5S7, Canada. E-mail: dnatcher@mun.ca 
of rural poverty, has proven less costly to state administration, and has helped to reduce some of the conflict associated with resource exploitation (Edmunds and Wollenberg 2003). Today, devolution is occurring in more than 60 countries throughout the world and involves the local management of forests, rangelands, irrigation systems, fisheries, and wildlife resources (Colfer and Capistrano 2005).

The extent to which indigenous peoples have achieved administrative authority for lands and resources has, however, varied, owing to conditions of community cohesion, political dynamics, financial constraints, and the general (un)willingness of some states to relinquish administrative power (Gregerson et al. 2005). These limiting factors are particularly apparent in Canada's Yukon Territory, where despite having settled comprehensive land claims, state institutions for land and resource management (and the ideologies that support them) remain deeply embedded within First Nation administration. While the language of devolution and local control permeates local-state interaction, the new institutions that have been created via the land claims process have little resemblance to indigenous forms of governance and management. Believing that devolution would resolve many of the perceived shortcomings associated with state-administered management, devolution in practice has led neither to ideological nor to structural reform. As a result, the concept of devolution, as applied in the Yukon, remains obscure, if not meaningless, to many First Nation people, and the management of natural resources continues to represent one of the most pervasive remnants of the colonial experience (Nadasdy 2003). In this article, we present some of the institutional and ideological factors that continue to influence the way in which lands and resources are managed in the Yukon Territory. In doing so, we draw attention to the difficulties of applying indigenous cultural ideals into a management process that is derived from nonindigenous values and principles.

\section{Devolution in the Yukon}

In Canada, the process of devolution first gained public attention with the signing of the James Bay and Northern Quebec Agreement (JBNQA) in 1975. This comprehensive land claims agreement, the first of its kind in Canada, was intended to put an end to jurisdictional debates between the Cree and Inuit of James Bay and northern Quebec and the federal and provincial governments. Under the terms of the JBNQA, devolution has proven effective at restoring specific rights and responsibilities to the Cree and Inuit for land and resource management.

The political mobilization that transpired following the JBNQA provided considerable leverage to other First Nations in Canada to initiate similar political processes. In the Yukon Territory, the political organization of the Council of Yukon Indians resulted in the long negotiated settlement of the Yukon Umbrella Final Agreement (UFA) in 1993. Providing a wide range of provisions (health, social services, economic development), the UFA also allocated $41,595 \mathrm{~km}^{2}\left(16,060 \mathrm{mi}^{2}\right)$ of settlement lands to First Nation governments. Representing nearly $9 \%$ of the Yukon's total land base, this territorial allocation includes responsibility for resource management and land use planning. With management responsibility for settlement lands, Yukon First Nations have the authority to establish bylaws for use and occupation, to develop and administer land management programs, and to levy fees for the use of land within the settlement region. To oversee these responsibilities, Yukon First Nations have each established Lands and Resource Departments under the authority of their First Nation governments. The role of these departments generally 
includes the delivery of various land management programs, to provide advice and direction to First Nation leadership on matters pertaining to land use and development, and to oversee any activity occurring on settlement lands, including wildlife harvesting, resource development, and research. The administrative body that forms these departments most often includes a lands director, an operations manager, and a technical support staff. With localized authority, First Nation governments have assumed the roles formerly held by federal land management agencies.

\section{Challenges of Devolution}

With the settlement of comprehensive land claims, Yukon First Nations have secured administrative responsibility for a significant amount of territorial land. This responsibility has, however, proven problematic for many First Nation governments. Aside from an intimate knowledge of the land, contemporary resource management also requires organizational skills and knowledge of government regulations. In fact, Meinzen-Dick et al. (1998) argue that the skills in dealing with government or market agencies may be as equally critical for successful management as knowledge of the resource base itself. These necessary skills include knowledge of government regulations, environmental policies, and some measure of technical and scientific literacy. Tanner (2001) has noted, however, that there are special difficulties for demographically small Aboriginal communities to recruit from their own ranks enough trained and talented individuals to assume management responsibilities. This point was highlighted during a workshop hosted by the First Nation Forestry Program in Whitehorse, Yukon, where the lack of internal capacity among First Nations was identified as being a significant challenge to the effective management of settlement lands (FNFP 2001). While acknowledging that First Nations possess a high degree of indigenous knowledge regarding local resources, the lack of "technical" knowledge of ecological dynamics can, according to workshop participants, hinder local management efforts. The lack of technical capacity among First Nations was also identified in a report prepared by the Aboriginal Forestry Training and Employment Review (AFTER) that concluded: "[Because] Aboriginal groups are exercising control over natural resources on large areas, and will have a strong voice in resource management on other lands in their traditional use areas ...more trained Aboriginal foresters, wildlife managers, range managers, and other professionals, technicians and workers are required" (Hopwood et al. 1993, 7). Although there are some indications that more Aboriginal people are receiving professional training in natural resource management fields (Parsons and Prest 2003), to date Aboriginal representation remains limited. ${ }^{1}$ As a result, First Nation governments continue to be challenged by a lack of personnel who are capable of assuming key administrative positions within First Nation governments.

This situation has in many ways lent support to the argument made by some government officials who oppose devolution on grounds that First Nations lack many of the basic skills needed to manage resources effectively. Without a track record of local management capacity, some government resource managers feel they are being asked to take a leap of faith in those who have limited management experience (Knox and Meinzen-Dick 2001). For instance, Wortley et al. (2001) found that among Yukon government land managers there is a general belief that First Nations lack a sufficient understanding of forest dynamics to make any real contributions to the management process. As a result, government managers are 
reluctant to devolve true authority to local levels in fear of uninformed management outcomes and feel justified in accepting only the recommendations that conform to predetermined government planning objectives. To First Nation leaders this attitude indicates an obvious lack of trust and confidence in First Nations' ability to manage the settlement regions and has further entrenched the belief in government that First Nations are ill prepared to assume control over their own affairs (Natcher et al. 2004).

With only a limited number of First Nation members having received professional training or relevant work experience in the natural resource management fields, some First Nation governments now find themselves forced to hire non-First Nation staff to fill key administrative roles (FNFP 2001). In many cases, non-First Nation residents who may have some previous employment experience with government land management agencies, and are familiar with the bureaucratic and technical complexity of contemporary resource management, are hired to fill these management positions. In other cases, government employees themselves have been reassigned to individual First Nations for periods of time in order to help transfer the necessary management skills to First Nation members. ${ }^{2}$ Despite their often best intentions, these non-First Nation employees cannot help but apply their own ideologies and cultural frames of reference to the land management process - a cultural frame of reference that is grounded in the Western resource management tradition. When confronted with deadlines, planning objectives, and program administration, non-First Nation staff tend to emulate the authoritarian practices learned elsewhere (Schuurman 2001). This often involves the adoption of complex decision-making processes involving resource inventories, wildlife assessments, management programs, policy initiatives, and the internal duplication of state administrative bureaucracies. The result is a centralized system of management that, like the territorial and federal departments, flows from the top down, with land managers remaining largely isolated from First Nation members. With non-First Nation managers being ideologically inaccessible to most First Nation members, the management of settlement lands is seen by many First Nation members as a mere extension of government administration (Nadasdy 2003).

\section{An Example of Aboriginal Resource Management}

Responding to these conditions, some Yukon First Nations are taking steps to revitalize traditional forms of management that are more reflective of First Nation values. For example, the Northern Tutchone Council (NTC), which represents the Little Salmon Carmacks, Selkirk, and Nacho Nyak Dun First Nations, is now in the process of reimplementing traditional laws related to the use and occupation of settlement lands. Referred to as Doo'Li, or a spiritually driven form of traditional law, these rules are now being recorded and applied to the management of the NTC settlement region. Resting in traditional knowledge, laws, and institutions that are specific to land management, the use of Doo'Li is considered by the NTC leadership as being essential to devolution and their successful transition to self-government.

By working directly with Northern Tutchone elders, traditional codes of conduct are being recorded and institutionalized into contemporary land management policy. This has involved the recording of species-specific laws and traditions that will be used to govern First Nation land management programs. Rather than an overt form 
of management, Doo'Li is a means by which social relationships, both human and nonhuman, can be maintained and, in some cases, rebuilt. For example, owing to the significance of salmon to Northern Tutchone First Nations, specific elements of Doo'Li that have long been observed are now being institutionalized into First Nation fisheries policy. Some of these are: prohibiting the shooting of bears near salmon spawning grounds; avoiding touching the eyes of salmon; disposing of fishnets by burning if an otter is snared; never putting fish in a dry pot and pouring water over them; prohibiting children from stepping over fishnets; and always leaving some fish for the bears, eagles, and other animals. Representing symbolic gestures believed necessary for the annual return of salmon, Doo'Li also serves as an adaptive mechanism by which contemporary concepts of Western resource management (i.e., sustainable use) can be translated by referencing traditional Northern Tutchone values. While proving more amenable to First Nation members, Doo'Li also represents a form of resistance against the colonial mind set of "managing resources."

For non-First Nation residents who seek access to settlement lands, they too are asked to abide by Doo'Li. In such cases, non-First Nation residents are required to report to the Land and Resource offices of the respective First Nation to receive written permission, or Ne Ya Ne Chat, which means "I give you food." At this time, they receive instruction on the principles of Doo'Li; an information packet outlining species-specific Doo'Li (to date, salmon, moose, caribou, furbearers, birds, and small game); a Resource Sharing Form that is to be returned to the Lands and Resource office with a small portion of their catch to be shared with First Nation elders; a newsletter explaining the efforts made by the NTC to care for their traditional territory; and a map identifying open access areas. While rooted in Northern Tutchone tradition, new elements of Doo'Li are also being introduced in order to respond to the complexity of the contemporary world. This has involved the development of enforcement and regulatory regimes, public education programs, and the development of school curriculum materials. For First Nation members, these strategies demonstrate a compatibility with modernity and lend additional relevancy to Doo'Li among First Nation members. Thus, by revitalizing traditional forms of stewardship, the Northern Tutchone see themselves on a path towards selfempowerment that will lead ultimately to liberation and autonomy.

It is important to note that although the NTC has the authority to enforce both Doo'Li and non-Doo'Li regulations on settlement lands through fines, the confiscation of equipment, eviction, and/or the denial of future access, enforcement at this point represents a secondary objective. Rather, the NTC sees educating those who are unfamiliar, whether First Nation or non-First Nation, on the alternative ways of managing relationships with the land as the most important task. That said, Northern Tutchone leaders are well aware that change will not occur overnight or by simple prescription. Because Doo'Li has to a large extent been undermined by decades of state administration, many elements of Doo'Li have been weakened and in some cases lost to government control. As such, one cannot expect traditional institutions to resurface automatically in the wake of government withdrawal, or as the colonial experience has shown, to be imposed from above. Rather, success will depend on the rebuilding of trust in First Nation authority and the generation and sustaining of effective forms of collective action among First Nation and nonFirst Nation members. While social networks and kinship obligations among First Nations will contribute in part to the observance of Doo'Li, success will require a significant measure of voluntary adherence. However, if government is willing to 
show respect for First Nation institutions, as well as publicly endorse First Nation accomplishments, others may be encouraged to accept Doo' $\mathrm{Li}$ as a legitimate institution. Therefore the successful implementation of Doo'Li, as well as other First Nation institutions, will depend on the level of commitment shown by government as well as the shared sense of responsibility among First Nation members.

\section{Politics of Devolution}

Although devolution has enabled the NTC to implement local institutions that are reflective of First Nation values, in many ways the NTC, as well as all Yukon First Nations, continues to be challenged by the embeddedness of government influence in First Nation affairs. While true devolution requires a genuine transfer of administrative authority (Colfer and Capistrano 2005), the reliability of financial support is equally critical to the successful transfer of management responsibility (Uphoff 1986). This is proving true in the Yukon, where First Nations find themselves challenged by government's failure to allocate sufficient funds to support the new demands First Nations now face (Natcher et al. 2005). Although the Devolution Transfer Agreement has allocated financial support to assist First Nations in comprehensive land use planning, the one-time collective payment of $\$ 3$ million has proven far from adequate. As such, Yukon First Nations lack the financial means to effectively identify and document First Nation values and resource management objectives (FNFP 2001). This situation is certainly not unique to the Yukon in that devolution has often resulted in heightened responsibility for indigenous peoples but not the appropriate budget or resources to make meaningful decisions (Enters et al. 2000; Howitt 2001). Nonetheless, due to this failure to allocate sufficient funds for land use planning, tension between the federal, territorial, and First Nation governments persist, and First Nations continue to find themselves laboring in "financial strait jackets" when it comes to policy implementation and administration (Prince and Abele 2002, 2). For devolution to have any significant impact, First Nations who have received new responsibilities require not only decision-making authority but also the financial resources to implement change (Doornbos et al. 2000). However, the high degree of conditionality attached to funding has limited the ability of First Nations to implement alternatives to existing government programs. This "carrot and stick approach" to government funding is perpetuating not only government institutions but also the expression of government values (Prince and Abele 2002, 2). From the perspective of some First Nation leaders, this clearly exemplifies government's desire to maintain the conditions that were in place prior to devolution.

This situation was thought to be potentially remedied by the April 1, 2003, transfer of administrative responsibility from the federal to the territorial government. As of this date the Yukon government assumed management responsibility for all public lands, waters, forests, mineral resources, and environmental assessment processes in the territory. With greater authority being exercised at the territorial level, it was believed that the Yukon government would prove more responsive to needs and concerns of Yukon First Nations. However, despite the transfer of administrative authority, the Yukon government enacted specific legislation that mirrored preexisting federal policy. This includes five legislative bills passed by the Yukon General Assembly that ensure the continuance of federal land management programs: the Environmental Assessment Act (Bill 66), the Placer Mining Act (Bill 67), the Quartz Mining Act (Bill 68), the Territorial Lands Acts (Bill 69), and the Waters Act 
(Bill 70). To administer these programs, many employees who had been responsible for federal administration received departmental transfers to the territorial government. As a result, First Nations now find themselves forced to deal with the same regulatory regime that was in place prior to administrative transfer and must continue to negotiate with many of the same individuals who opposed devolution from the outset. Thus, despite devolution, Yukon First Nations are encountering the same administrative and ideological legacy left by the federal regime. Far from devolving responsibility, the administrative transfer that is taking place in the Yukon is more consistent with deconcentration in that real authority and accountability remain in the hands of the same form of government (Meinzen-Dick et al. 1998). Representing two very distinct processes, deconcentration has left Yukon First Nations skeptical as to whom is actually "calling the shots" in regard to land management in the Yukon (FNFP 2001).

\section{Conclusion}

While it is arguably the case that the formal relations between the federal, territorial, and First Nation governments have changed since the signing of the UFA, it is also true that the territorial government remains ever present and deeply embedded in the new institutions designed to empower First Nations in the land management process. Although the settlement of comprehensive land claims offers some opportunities to implement new forms of management that are consistent with First Nation traditions and beliefs (i.e., Doo'Li), the entrenchment of the state system continues to limit the extent to which First Nations are empowered to propose and implement change. Rather than empowering First Nations, the pervasiveness of state management has in effect perpetuated historical conditions where First Nation governments have gained little autonomy in the management of lands and resources. The theoretical advantages of devolution are certainly convincing (Gibson et al. 2000), and the impetus for administrative transfer strong (Agrawal and Gibson 2001), but the actual outcome in the Yukon has yet to live up to First Nation expectations. Thus, despite the rhetoric of local-level decision making, real authority remains concentrated in government administration.

This article has addressed the challenges associated with devolution in the Yukon Territory, yet these same issues will no doubt prove relevant to other First Nations in Canada who are negotiating their own devolution and self-government agreements, for example, the Innu Nation in Labrador and several First Nations in British Columbia. Before entering into these agreements it will be imperative that First Nation leaders think critically as to whether devolution, as currently implemented in Canada, can create conditions of empowerment and autonomy for First Nation governments or merely represents the deconcentration of preexisting forms of state management and the perpetuation of values that support them.

\section{Notes}

1. For instance, as of 2003 there were only 17 registered professional foresters of Aboriginal descent in Canada (Parsons and Prest 2003).

2. For example, the coauthor (Davis) was an employee of the Yukon Government who had been reassigned to the Little Salmon Carmacks First Nation to assist them in the administration of their Land and Resources Department. 


\section{References}

Agrawal, A. and C. Gibson (Eds.). 2001. Communities and the environment: Ethnicity, gender and the state in community-based conservation. New Brunswick, NJ: Rutgers University Press.

Colfer-Pierce, C. and D. Capistrano (Eds.). 2005. The politics of decentralization: Forests, power and people. London: Earthscan.

Doornbos, M., A. Saith, and B. White (Eds.). 2000. Forests: Nature, people, power. Oxford, UK: Blackwell.

Edmunds, D. and E. Wollenberg (Eds.). 2003. Local forest management: The impacts of devolution policies. London: Earthscan.

Enters, T., P. B. Durst, and M. Victor. 2000. Decentralization and devolution of forest management in Asia and the Pacific. RECOFTC Report No. 18 and RAP Publication 2000/1. Bangkok, Thailand.

First Nations Forestry Program. 2001. Forest based values and economic opportunities for Yukon First Nations: Key issues, challenges and solutions. FNFP Workshop Proceeding, March 6-9, Whitehorse, Yukon Territory. Ottawa, Ontario: Natural Resource Canada.

Gibson, C., M. McKean, and E. Ostrom (Eds.). 2000. People and forests: Communities, institutions and governance. Cambridge, MA: MIT Press.

Gregerson, H., A. Contreras-Hermosilla, A. White, and L. Phillips. 2005. Forest governance in federal systems: An overview of experiences and implications for decentralization. In The politics of decentralization: Forests, power and people, eds. C. J. Pierce-Colfer and D. Capistrano, 13-31. London: Earthscan.

Hopwood, A., J. Mactavish, A. Moar, G. Scott, and P. Smith. 1993. Aboriginal Forestry Training and Employment Review (AFTER): Phase I final report. Ottawa, Ontario: National Aboriginal Forestry Association.

Howitt, R. 2001. Rethinking resource management: Justice, sustainability, and indigenous peoples. New York: Routledge Press.

Knox, A. and R. Meinzen-Dick. 2001. Collective action, property rights, and devolution of natural resource management: Exchange of knowledge and implications for management. Washington, DC: International Food Policy Research Institute.

Meinzen-Dick, R., A. Knox, and P. Hazell. 1998. Property rights, collective action and technologies for natural resource management: A conceptual framework. Washington, DC: International Food Policy Research Institute.

Nadasdy, P. 2003. Hunters and bureaucrates: Power, knowledge, and aboriginal-state relations in the Southwest Yukon. Vancouver: University of British Columbia Press.

Natcher, D., S. Davis, and C. Hickey. 2005. Co-management: Managing relationships, not resources. Hum. Organiz. 64(3):240-250.

Natcher, D., C. Hickey, and S. Davis. 2004. The political ecology of Yukon forestry: Managing the forest as if people mattered. Int. J. Sustain. Dev. World Ecol. 11:343-355.

Parsons, R. and G. Prest. 2003. Aboriginal forestry in Canada. For. Chron. 79(4):779-784.

Prince, M. and F. Abele. 2002. Paying for self-determination: Aboriginal peoples, self-government, and fiscal relations in Canada. Paper presented at the Conference, Reconfiguring Aboriginal-State Relations, Canada: The State of the Federation 2003. Institute of Intergovernmental Relations, School of Policy Studies, Queen's University, Ontario, Canada. November 1-2.

Ribot, J. and A. Larson. 2005. Democratic decentralization through the natural resource lens. London: Routledge Press.

Schuurman, H. 2001. The concept of community and the challenge for self-government. In Aboriginal autonomy and development in Northern Quebec and Labrador, ed. C. H. Scott, 379-395. Vancouver: University of British Columbia Press.

Tanner, A. 2001. The double bind of aboriginal self-government. In Aboriginal autonomy and development in Northern Quebec and Labrador, ed. C. H. Scott, 396-416. Vancouver: University of British Columbia Press. 
Uphoff, N. 1986. Local institutional development: An analytical source book with cases. West Hartford, CT: Kumarian Press.

Wortley, D., N. Krogman, and D. Davidson. 2001. The difficulties with devolution: Community-based forest management planning in the yukon under comprehensive land claims. Sustainable Forest Management Network, Project Report 2001-28. Edmonton: University of Alberta. 